\title{
KatARZyna SERAFin
}

Uniwersytet Łódzki

\section{PRAWO DO URLOPU OJCOWSKIEGO W POLSKIEJ REGULACJI PRAWNEJ}

Nowelizacją z dnia 6 grudnia 2008 r. ${ }^{1}$ wprowadzono do Kodeksu pracy nieznaną wcześniej polskiemu prawu instytucję urlopu ojcowskiego. Zgodnie z nowymi przepisami, prawo do takiego urlopu przysługuje pracownikowi-ojcu wychowującemu dziecko do ukończenia przez dziecko 12 miesiąca życia. Jest to własne, samodzielne uprawnienie pracownika-ojca, niezależne od innych uprawnień pracowniczych związanych z rodzicielstwem. W odróżnieniu od urlopu macierzyńskiego czy urlopu rodzicielskiego nie jest ono gwarantowane w przepisach międzynarodowego prawa pracy, ani w regulacjach prawa unijnego. W aktach tworzonych przez Międzynarodową Organizację Pracy nie wymienia się w ogóle takiego uprawnienia. Natomiast w przypadku prawa unijnego urlop ojcowski pojawia się w regulacjach Dyrektywy 2002/73 Parlamentu Europejskiego i Rady z 23 września 2002 r. zmieniającej Dyrektywę Rady 76/207 z 9 lutego 1976 dotyczącą wdrożenia zasady równego traktowania mężczyzn i kobiet w zakresie dostępu do zatrudnienia, kształcenia zawodowego i awansu oraz warunków pra$\mathrm{cy}^{2}$. Zgodnie $\mathrm{z}$ art. 2 ust. 7, dyrektywa ta nie stanowi przeszkody dla

${ }^{1}$ Ustawa z 6 grudnia 2008 r. o zmianie ustawy - Kodeks Pracy oraz niektórych innych ustaw, Dz.U. z 2008 r. Nr 237, poz. 1654.

${ }^{2}$ Directive 2002/73/EC of the European Parliament and of the Council of 23 September 2002 amending Council Directive 76/207/EEC on the implementation of 
państw członkowskich w wyraźnym uznaniu praw do urlopu ojcowskiego lub adopcyjnego. Jeżeli jednak państwo członkowskie zdecyduje się uznać takie prawo, zobowiązane jest podjąć niezbędne środki w celu ochrony pracujących mężczyzn przed zwolnieniem z powodu korzystania $\mathrm{z}$ tego urlopu i zapewnić, że po zakończeniu urlopu będą mieli oni prawo do powrotu na swoje lub równoważne stanowiska pracy na warunkach nie mniej korzystnych oraz prawo do polepszenia warunków pracy, do których byliby uprawnieni podczas swojej nieobecności

Z powyższej krótkiej analizy wynika, że akty prawa ponadnarodowego, którymi Polska jest związana, nie zawierają nakazu, ani nawet wyraźnie nie postulują wprowadzenia do krajowego porządku prawnego takiego uprawnienia. Dopuszczają jedynie taką możliwość. Tym bardziej na podkreślenie zasługuje więc fakt, że polski ustawodawca zdecydował się uregulować tę kwestię. W ten sposób Polska dołączyła do grona państw europejskich, które przyznają pracującym ojcom prawo do tego szczególnego urlopu. Wśród państw, których ustawodawstwa zawierają wyraźne regulacje w tej kwestii, znajdują się m.in. kraje skandynawskie, Francja, Belgia, Monako oraz niektóre kraje postkomunistyczne jak np. Węgry czy Rumunia ${ }^{3}$.

Polskie przepisy dotyczące możliwości korzystania z urlopu ojcowskiego obowiązują od dnia 1 stycznia 2010 r. Zgodnie z art. $182^{3}$ $\S 1$ k.p., pracownikowi-ojcu wychowującemu dziecko przysługuje prawo do skorzystania z urlopu ojcowskiego do ukończenia przez dziecko 12 miesiąca życia. Może on skorzystać z tego urlopu niezależnie od korzystania przez matkę dziecka w tym samym czasie z urlopu macierzyńskiego, dodatkowego urlopu macierzyńskiego czy też urlopu wychowawczego.

Prawo do urlopu ojcowskiego nie jest uzależnione od rodzaju umowy o pracę będącej podstawą zatrudnienia pracownika ani posiadania określonego stażu pracy. Jednakże literalne ujęcie zwrotu „ojciec

the principle of equal treatment for men and women as regards access to employment, vocational training and promotion, and working conditions, OJ L 269, 05. 10. 2002

3 Informacje z bazy danych Międzynarodowej Organizacji Pracy, http://www.ilo. org/public//english//protection/condtrav/family/reconcilwf/specialleave.htm 
wychowujący dziecko" zawęża kragg osób, które mogą skorzystać $\mathrm{z}$ urlopu ojcowskiego, eliminując $\mathrm{z}$ ich grona tych pracowników, którzy porzucili rodzinę i nie zajmują się dzieckiem. W praktyce jednak może być trudno wykazać ten fakt. Urlopu ojcowskiego udziela się bowiem na pisemny wniosek pracownika, który pracodawca ma obowiązek uwzględnić. Wykonanie tego obowiązku nie jest więc uzależnione od przedstawienia przez pracownika dowodów na to, że wychowuje on dziecko ${ }^{4}$. Przykładowo, pozostawanie w formalnym związku małżeńskim z matką dziecka nie musi świadczyć o wychowywaniu dziecka przez ojca, ponieważ mogą się zdarzyć sytuacje, że małżonkowie są skłóceni i nie mieszkają ze sobą. Ponadto istnieje wiele związków nieformalnych, w których partnerzy wspólnie wychowują dzieci. $Z$ drugiej strony, separacja czy rozwód też nie zawsze decydują o tym, że ojciec nie wychowuje dziecka, bowiem zgodnie z przepisami art. 58 oraz $61^{3}$ k.r.i.o ${ }^{5}$, orzekając rozwód bądź separację małżonków sąd może pozostawić władzę rodzicielską obojgu rodzicom na ich zgodny wniosek.

Mimo że przepis art. $182^{3}$ k.p. wyraźnie nie określa, od jakiego momentu pracownik jest uprawniony do skorzystania z prawa do urlopu, należy uznać, że formalna droga do zrealizowania tego uprawnienia otwiera się z chwilą (a ściślej datą) narodzin dziecka. O pracownikuojcu wychowującym dziecko można bowiem mówić dopiero wtedy, gdy dziecko pojawi się na świecie. Nie oznacza to jednak, że pracownik będzie mógł pójść na urlop już w dniu narodzin dziecka. Do takiego wniosku skłania lektura $\S 2$ art. $182^{3}$ k.p., określającego procedurę udzielania urlopu ojcowskiego. Zgodnie z tym przepisem, pracodawca udziela pracownikowi-ojcu wychowującemu dziecko urlopu na jego pisemny wniosek, składany w terminie nie krótszym niż 7 dni przed rozpoczęciem korzystania z urlopu. Użyte także w tym paragrafie sformułowanie „ojciec wychowujący dziecko” sugeruje, że wnio-

${ }^{4}$ Pracownik powinien jednak dołączyć do wniosku skrócony odpis aktu urodzenia dziecka, niezbędny do przyznania i wypłacenia zasiłku macierzyńskiego, który przysługuje pracownikowi za czas urlopu, o czym będzie jeszcze mowa później.

${ }^{5}$ Ustawa z dnia 25 lutego 1964 r. - Kodeks rodzinny i opiekuńczy, Dz.U. z 1964 r. $\mathrm{Nr}$ 9, poz. 59 ze zm. 
sek o udzielenie urlopu ojcowskiego może być złożony najwcześniej z datą narodzin dziecka. Nie można bowiem wychowywać dziecka, które się jeszcze nie narodziło. W praktyce problem ten może nie mieć większego znaczenia $\mathrm{z}$ uwagi na fakt, że w przeważającej mierze poród odbywa się w szpitalu i zazwyczaj kobieta pozostaje tam kilka dni po porodzie. Poza tym należy pamiętać, że zgodnie z $§ 15$ pkt 1 Rozporząazenia MPiPS w sprawie sposobu usprawiedliwiania nieobecności w pracy oraz udzielania pracownikom zwolnień od pracy ${ }^{6}$, pracodawca ma obowiązek zwolnić od pracy pracownika na czas obejmujący 2 dni w przypadku urodzenia się jego dziecka.

Określając czas trwania urlopu ojcowskiego przepis art. $182^{3} \mathrm{k}$.p. stanowi, że urlop ten przysługuje w wymiarze 2 tygodni. Jednak do prawidłowego ustalenia jego długości niezbędne jest sięgnięcie do przepisów ustawy nowelizacyjnej. Według art. 14 ust. 2, wymiar urlopu ojcowskiego wynosi w 2010 r. i 2011 r. jeden tydzień. Zatem wymiar dwutygodniowy wskazany w kodeksie pracy zacznie obowiązywać dopiero od 1 stycznia 2012 r. W odniesieniu do pracownika przebywającego na urlopie ojcowskim w dniu 1 stycznia 2012 r. art. 15 ustawy przewiduje prawo do skorzystania z części urlopu w wymiarze odpowiadającym różnicy pomiędzy podwyższonym a dotychczasowym wymiarem urlopu. Zgodnie z tym przepisem, części urlopu ojcowskiego udziela się bezpośrednio po wykorzystaniu urlopu w dotychczasowym wymiarze. Przesłanką udzielenia urlopu jest złożenie pisemnego wniosku przez pracownika w terminie nie krótszym niż 3 dni przed rozpoczęciem korzystania $\mathrm{z}$ takiej części urlopu. Zgodnie $\mathrm{z}$ art. $183^{1} \S 1$ k.p. w związku $\mathrm{z}$ art. $182^{3} \S 3$ k.p. tydzień urlopu odpowiada 7 dniom kalendarzowym, co oznacza, że urlop ojcowski obejmuje zarówno dni robocze, jak i świąteczne.

Trzeba stwierdzić, że zarówno przepis art. $182^{3}$ k.p., jak i przepisy ustawy nowelizacyjnej w części dotyczącej wymiaru urlopu ojcowskiego są dość niejasne i wzbudzają w związku z tym szereg wątpliwości interpretacyjnych. Zgodnie z brzmieniem art. $182^{3}$ k.p., ,pracownik-

\footnotetext{
${ }^{6}$ Rozporządzenie Ministra Pracy i Polityki Społecznej z dnia 15 maja 1996 r. W sprawie sposobu usprawiedliwiania nieobecności w pracy oraz udzielania pracownikom zwolnień od pracy, Dz.U. z 1996 r. Nr 60, poz. 281 ze. zm.
} 
ojciec wychowujący dziecko ma prawo do urlopu ojcowskiego w wymiarze 2 tygodni, nie dłużej jednak niż do ukończenia przez dziecko 12 miesiąca życia. Pierwsza wątpliwość, jaka pojawia się na tle tego przepisu, dotyczy zwrotu ,nie dłużej niż do ukończenia przez dziecko 12 miesiąca życia”. Nie wiadomo bowiem do czego odnosi się ten termin - do możliwości skorzystania z tego prawa czy też do samego wymiaru urlopu. Niewątpliwe jest, że pracownik powinien złożyć wniosek o urlop ojcowski przed upływem wskazanego powyżej terminu. Wydaje się również, że pracownik powinien rozpocząć urlop ojcowski przed ukończeniem przez dziecko 12 miesiąca życia, bo z nadejściem tej chwili uprawnienie wygaśnie. Powstaje natomiast pytanie, czy fakt ukończenia przez dziecko 12 miesiąca życia w trakcie korzystania przez ojca z urlopu automatycznie pociaga za sobą zakończenie urlopu ojcowskiego, co de facto oznacza skrócenie z mocy prawa czasu jego trwania, czy też fakt ten nie wpływa na długość takiego urlopu.

Podejmując próbę rozwiązania tej kwestii należy wcześniej ustalić charakter prawny wymiaru urlopu ojcowskiego, a mianowicie czy chodzi tu wyłącznie o maksymalną długość tego urlopu czy też wymiar ten ma charakter sztywny. Kategoryczne sformułowanie „w wymiarze 2 tygodni", zawarte $\mathrm{w} \S 1$ art. $182^{3}$ k.p., wskazuje moim zdaniem raczej na sztywny charakter wymiaru urlopu ojcowskiego. Gdyby ustawodawca chciał podkreślić jedynie maksymalny czas trwania takiego urlopu, zapewne posłużyłby się formuła „w wymiarze do", zastosowaną w odniesieniu do dodatkowego urlopu macierzyńskiego czy też urlopu wychowawczego Przy założeniu „sztywnego” wymiaru nie jest istotne, czy termin zakończenia urlopu ojcowskiego przypadnie przed czy po dacie ukończenia przez dziecko 12 miesiąca życia, bowiem w każdym przypadku pracownik nabywa prawo do urlopu w wymiarze wskazanym w przepisach.

Koncepcja „sztywnego" wymiaru urlopu ojcowskiego łączy się z przyjęciem tezy, że z urlopu tego można skorzystać wyłącznie jednorazowo w całości, mimo że kodeks pracy wyraźnie nie wskazuje na 
takie rozwiązanie ${ }^{7}$. Jedyny przypadek, w którym teoretycznie dopuszczalna byłaby przerwa w korzystaniu z urlopu, może być rozważany na gruncie przepisu art. 15 ustawy nowelizującej, normującego sytuację pracownika korzystającego z takiego urlopu w dniu 1 stycznia 2012 r. Przepis ten przyznaje pracownikowi prawo do części urlopu w rozmiarze odpowiadającym różnicy między podwyższonym a dotychczasowym wymiarem urlopu, o czym była już mowa wcześniej. Ta część urlopu również jest udzielana na pisemny wniosek pracownika, który należy złożyć w terminie nie krótszym niż 3 dni przed rozpoczęciem korzystania z takiej części. Zakładając zatem, że dzień 1 stycznia 2012 r. jest ostatnim dniem jednotygodniowego urlopu ojcowskiego i jednocześnie pierwszym dniem, w którym pracownik może złożyć wniosek o udzielenie mu kolejnej części urlopu (bo dopiero tego dnia nabędzie prawo do zwiększonego wymiaru urlopu), konieczność zachowania trzydniowego terminu między złożeniem wniosku a rozpoczęciem korzystania $\mathrm{z}$ drugiej części urlopu doprowadzi do powstania przerwy między tymi dwiema częściami. Takiemu rozumowaniu nie stoi na przeszkodzie fragment przepisu stanowiący, że części urlopu ojcowskiego udziela się bezpośrednio po wykorzystaniu urlopu w dotychczasowym wymiarze. Korzystanie przez pracownika w sposób nieprzerwany z urlopu ojcowskiego w takiej sytuacji byłoby możliwe pod warunkiem, że pracodawca udzieli pracownikowi drugiej części urlopu przed upływem trzech dni od daty złożenia wniosku, czego żaden przepis mu nie zabrania.

Formalnym warunkiem skorzystania $\mathrm{z}$ urlopu ojcowskiego jest uprzednie złożenie pisemnego wniosku $\mathrm{w}$ tej sprawie. Zgodnie $\mathrm{z}$ art. $182^{3} \S 2$ k.p., wniosek ma być złożony do pracodawcy $\mathrm{w}$ terminie nie krótszym niż 7 dni przed rozpoczęciem korzystania z urlopu. Pracodawca jest obowiązany uwzględnić wniosek pracownika. Choć kodeks pracy nie reguluje wyraźnie tej kwestii, celowe byłoby ozna-

${ }^{7}$ Niektóre $\mathrm{z}$ regulacji przyjętych $\mathrm{w}$ innych państwach dopuszczają jednorazowe skorzystanie z całego urlopu bądź podzielenie go na części według uznania pracownika (np. wyraźna regulacja w tym zakresie przewidziana jest w ustawodawstwie belgijskim. Tak stanowi art. $30 § 2$ de la loi du 3 juillet 1978 relative aux contrats de travail inséré par la loi du 2001 relative à la conciliation entre l'emploi et la qualité de vie). 
czenie przez pracownika we wniosku terminu rozpoczęcia korzystania z urlopu ojcowskiego, zwłaszcza jeśli pracownik chciałby zaplanować urlop z większym wyprzedzeniem. W przypadku niezamieszczenia takiej informacji należałoby bowiem przyjąć, że pracownik rozpocznie urlop po upływie 7 dnia od daty złożenia wniosku. Powstaje pytanie, jak należy kwalifikować sytuację, w której pracownik oznaczył we wniosku datę rozpoczęcia korzystania z urlopu ojcowskiego, ale wniosek został złożony w terminie krótszym niż 7 dni w stosunku do tej daty?

Kodeks nie określa konsekwencji uchybienia terminowi przez pracownika. Zważywszy jednak, że obowiązek udzielenia urlopu przez pracodawcę ma charakter bezwzględny, należy przypuszczać, że minimalny siedmiodniowy okres wprowadzony przez ustawodawcę ma na celu zabezpieczenie interesów pracodawcy. Pozwala mu przygotować się do nieobecności pracownika w pracy poprzez np. możliwość znalezienia zastępstwa czy też odpowiedniego rozplanowania zadań pomiędzy pozostałych pracowników. Wydaje się więc, że w sytuacji niezachowania powyższego terminu przez pracownika, obowiązek pracodawcy udzielenia urlopu przed upływem owych siedmiu przewidzianych prawem dni nie miałby charakteru bezwzględnego, a jedynie byłby realizowany w miarę możliwości. Dopiero po upływie siedmiu dni pracodawca musiałby bezwzględnie udzielić takiego urlo$\mathrm{pu}^{8}$. Oznaczałoby to, że pracodawca związany jest datą określoną we wniosku tylko przy zachowaniu przez pracownika ustawowego siedmiodniowego terminu do jego złożenia.

Pracownik wnoszący o udzielenie urlopu ojcowskiego powinien dołączyć do wniosku skrócony odpis aktu urodzenia dziecka. Obowiązek ten nie wynika bezpośrednio z przepisów kodeksu pracy, lecz z prze-

8 Tego typu konstrukcję zastosowano w $\S 3$ ust. 3 Rozporządzenia Ministra Gospodarki, Pracy i Polityki Społecznej z dnia 16 grudnia 2003 r. w sprawie szczegółowych warunków udzielania urlopu wychowawczego (Dz.U. z 2003 r. Nr 230, poz. 2291), zgodnie z którym, jeżeli wniosek o udzielenie urlopu wychowawczego zostanie złożony bez zachowania terminu, o którym mowa w $\S 1$ (2 tygodnie przed datą rozpoczęcia urlopu wychowawczego), pracodawca udziela urlopu wychowawczego nie później niż z dniem upływu 2 tygodni od dnia złożenia przez pracownika wniosku. 
pisów wykonawczych do ustawy o świadczeniach pieniężnych z ubezpieczenia społecznego z tytułu choroby i macierzyństwa ${ }^{9}$, bowiem jak stanowi art. 184 k.p., za czas urlopu ojcowskiego pracownikowi przysługuje zasiłek macierzyński, regulowany przepisami wyżej wskazanej ustawy. Zgodnie zaś z odpowiednią interpretacją przepisów wykonawczych wydanych na jej podstawie, dokumentem stanowiącym dowód do przyznania i wypłaty zasiłku macierzyńskiego jest skrócony odpis aktu urodzenia ${ }^{10}$.

Korzystanie przez pracownika-ojca wychowującego dziecko z urlopu ojcowskiego może wpłynąć na zaplanowany wcześniej urlop wypoczynkowy. W tym przypadku dopuszczalne są odstępstwa od zasady planowego udzielania urlopów. Po pierwsze, na wniosek pracownika pracodawca udziela mu urlopu wypoczynkowego bezpośrednio po urlopie ojcowskim (art. $163 \S 3$ k.p. w związku z art. $182^{3} \S 3$ k.p.). Po drugie, jeśli z powodu korzystania z urlopu ojcowskiego pracownik nie może rozpocząć urlopu wypoczynkowego w ustalonym terminie, pracodawca ma obowiązek przesunąć urlop wypoczynkowy i udzielić go pracownikowi w późniejszym terminie (art. 165 pkt 4 i art. 166 pkt $4 \mathrm{w}$ związku z art. $182^{3} \S 3$ k.p.).

Stosunek pracy pracownika korzystającego z urlopu ojcowskiego podlega szczególnej ochronie przed wypowiedzeniem i rozwiązaniem w zakresie przewidzianym w art. 177 k.p. (art. $182^{3} \S 3$ k.p.). Oznaczałoby to, że pracodawca nie może wypowiedzieć ani rozwiązać $\mathrm{z}$ pracownikiem umowy o pracę $\mathrm{w}$ okresie korzystania $\mathrm{z}$ urlopu, chyba że zachodzą przyczyny uzasadniające rozwiązanie niezwłoczne z winy pracownika, a reprezentująca go zakładowa organizacja związkowa wyraziła zgodę na rozwiązanie umowy. Wypowiedzenie umowy pracownikowi korzystającemu z urlopu ojcowskiego dopuszczalne

${ }^{9}$ Ustawa z dnia 25 czerwca 1999 r. o świadczeniach pieniężnych z ubezpieczenia społecznego w razie choroby i macierzyństwa, t.j. Dz.U. z 2005 r. Nr 31, poz. 267 ze. $\mathrm{zm}$.

${ }^{10} \S 12$ pkt 1 Rozporządzenia Ministra Pracy i Polityki Socjalnej z dnia 27 lipca 1999 r. w sprawie określenia dowodów stanowiących podstawę przyznania i wypłaty zasiłków z ubezpieczenia społecznego w razie choroby i macierzyństwa, Dz.U. z 1999 r. $\mathrm{Nr}$ 65, poz. 742 ze. zm. 
jest wyłącznie w przypadku ogłoszenia upadłości lub likwidacji pracodawcy. W takiej sytuacji przepis nakazuje pracodawcy uzgodnić z zakładową organizacją związkową reprezentującą pracownika termin rozwiązania umowy o pracę. Wydaje się jednak, że z uwagi na stosunkowo niski wymiar urlopu ojcowskiego ta ostatnia regulacja będzie miała niewielkie zastosowanie w praktyce.

Szczególną ochroną trwałości stosunku pracy nie będzie objęty pracownik zatrudniony na podstawie umowy na okres próbny nieprzekraczający miesiąca.

Zastosowanie przez ustawodawcę zabiegu legislacyjnego polegającego na odesłaniu do odpowiedniego stosowania innego przepisu w odniesieniu do art. 177 k.p. nie jest najlepszym rozwiązaniem. Ochrona przewidziana w tym artykule z założenia obejmuje dość długi okres (ciąża i urlop macierzyński), co sprawia, że w stosunku do krótkiego urlopu ojcowskiego większość zapisanych w przepisie rozwiązań staje się nieracjonalna. Co więcej, stwarza pole do nadużyć dla pracownika. Przy założeniu, że wcześniej wypowiedziana umowa nie może się rozwiązać w okresie ochronnym, pracownik byłby w stanie „zablokować" wypowiedzenie zarówno umowy bezterminowej, jak i umowy na czas określony, składając w „odpowiednim” czasie (po dokonaniu wypowiedzenia przez pracodawcę) wniosek o udzielenie urlopu ojcowskiego. Odmawiając cofnięcia oświadczenia woli o wypowiedzeniu pracodawca naruszyłby przepisy o wypowiedzeniu umowy o pracę, co pozwoliłoby pracownikowi wystapić przeciwko niemu z roszczeniami do sądu pracy. Zważywszy, że zgodnie z art. $182^{3}$ $\S 3$ k.p., do pracownika korzystającego z urlopu ojcowskiego stosuje się także odpowiednio przepisy art. $45 \S 3$, art. 47 , art. $50 \S 5$ oraz art. $57 \S 2$ k.p., dochodzi do kuriozalnej sytuacji. Oto bowiem w przypadku bezprawnego wypowiedzenia pracownik (także ten zatrudniony na podstawie umowy o pracę na czas określony!) może wystapić przeciwko pracodawcy do sądu $\mathrm{z}$ roszczeniem o przywrócenie do pracy. W stosunku do pracowników szczególnie chronionych sąd ma prawo nie uwzględnić żądania przywrócenia do pracy tylko w sytuacji ogłoszenia upadłości lub likwidacji pracodawcy. W przypadku wydania wyroku przywracającego do pracy, pracownikowi należałoby 
się wynagrodzenie za cały czas pozostawania bez pracy. Nawet jeśli $\mathrm{w}$ procesie przed sądem pracy pracodawca podniesie zarzut nadużycia przez pracownika prawa podmiotowego, a sąd powołując się na art. 8 k.p. nie zasądzi przywrócenia do pracy, to i tak będzie musiał orzec odszkodowanie.

Analizując treść przepisów, do których odpowiedniego stosowania odsyła ustawodawca w art. $182^{3} \S 3$ k.p., można przypuszczać, że jego zamiarem było dostosowanie polskich regulacji do postanowień cytowanej wcześniej Dyrektywy 2002/73 Parlamentu Europejskiego i Rady z 23 września 2002 r. zmieniającej Dyrektywę Rady 76/207 z 9 lutego 1976 dotyczącą wdrożenia zasady równego traktowania mężczyzn i kobiet w zakresie dostępu do zatrudnienia, kształcenia zawodowego i awansu oraz warunków pracy. Wydaje się jednak, że w tym przypadku ustawodawca potraktował wymóg równego traktowania mężczyzn i kobiet zbyt dosłownie. Zdecydowanie lepszym rozwiązaniem byłoby wprowadzenie osobnych przepisów ochronnych dostosowanych do specyfiki urlopu ojcowskiego, a nie odpowiednie stosowanie przepisu chroniącego kobiety w ciąży i na urlopie macierzyńskim.

Konieczność dostosowania prawa polskiego do postanowień wyżej wymienionej dyrektywy była również powodem ostatniej nowelizacji kodeksu pracy z dnia 5 listopada 2009 r., która weszła w życie 6 stycznia 2010 r. ${ }^{11}$ Nowelizacja ta wprowadziła do kodeksu pracy art. $183^{2}$ oraz odesłanie do odpowiedniego stosowania tego przepisu w art. $182^{3}$ $\S 3$ k.p. Na podstawie tych przepisów pracodawca ma obowiązek dopuścić pracownika po zakończeniu urlopu ojcowskiego do pracy na dotychczas zajmowanym stanowisku, a jeżeli nie jest to możliwe, na stanowisku równorzędnym z zajmowanym przed rozpoczęciem urlopu lub na innym stanowisku odpowiadającym jego kwalifikacjom zawodowym, za wynagrodzeniem za pracę, jakie otrzymywałby, gdyby nie korzystał z urlopu.

Oceniając całokształt regulacji prawa do urlopu ojcowskiego, po pierwsze należy odnotować sam fakt wprowadzenia takiej instytu-

${ }^{11}$ Ustawa z dnia 5 listopada 2009 r. o zmianie ustawy - Kodeks pracy, Dz.U. z 2009 r. Nr 219, poz. 1704. 
cji do prawa polskiego. Nie był to bowiem wyraz realizacji jakiegoś obowiązku wynikającego z prawa ponadnarodowego. W uzasadnieniu do projektu nowelizacji wprowadzającej m.in. urlop ojcowski nie ma w ogóle mowy o motywie, jakim kierował się ustawodawca wprowadzając do porządku prawnego tę instytucję. Wskazuje się tam wprawdzie na potrzebę wspierania i realizacji założeń polityki prorodzinnej i dostosowanie prawa polskiego do wymogów prawa unijnego w zakresie równego traktowania mężczyzn i kobiet, ale kwestii tych raczej nie można odnieść bezpośrednio do urlopu ojcowskiego. Nie wydaje się bowiem, by urlop ten miał wpływać na zwiększenie przyrostu naturalnego. Nie można go również uznać za przejaw zasady równego traktowania kobiet i mężczyzn.

$\mathrm{Z}$ drugiej zaś strony, przepis regulujący prawo do urlopu ojcowskiego jest sformułowany mało precyzyjnie i wzbudza liczne wątpliwości interpretacyjne. Nie zaszkodziłoby niewielkie rozbudowanie tej regulacji i usunięcie niejasności w zakresie sytuacji prawnej pracownika uprawnionego do takiego urlopu. Niewykluczone, że luki prawne zostaną wypełnione treścią przez orzecznictwo sądowe. Na to jednak trzeba będzie poczekać, zważywszy że przepis o urlopie ojcowskim wszedł w życie dopiero z początkiem bieżącego roku.

\section{The Right to Paternity Leave under the Polish Legislation}

\section{Summary}

By virtue of The Act of $8^{\text {th }}$ December 2008 amending the Labour Code a new legal institution - paternity leave has been introduced into Polish labour law. Since $1^{\text {st }}$ January 2010 an employee-father is entitled to paternity leave upon the event of childbirth. This right is not assignable. Furthermore, it is irrespective of other parental rights. The father may use the right to paternity leave by the time the child is twelve months old. During the use of that leave the father is protected against the termination of labour contract. Under the article $182^{3}$ of the Labour Code an employee has the right to paternity leave in the amount of two weeks. However, according to 
provisions of The Act of $8^{\text {th }}$ December 2008, the above mentioned duration of paternity leave will be in force from $1^{\text {st }}$ January 2012. Until that date the father is entitled to one week of paternity leave only.

Introduction of the paternity leave into the Polish labour law should be approved. However, it seems that the reading of that new regulation as well as the legal constructions adopted for the purpose of an effective use of the right to paternity leave may cause some doubts and interpretative problems. The paper is an attempt of a general analysis of all provisions of the Labour Code regulating the use of right to paternity leave. 